\title{
Effect of Capital Strengthening, Education, and Health on Poverty Status in the City of Sawahlunto
}

\author{
Afridarman $^{1 *}$, Syamsul Amar ${ }^{2}$, Hasdi Aimon ${ }^{3}$ \\ 1,2,3 Universitas Negeri Padang, Padang, Indonesia \\ *Corresponding author. Email: afridarman@gmail.com
}

\begin{abstract}
This study aims to reveal and analyze the effect of capital strengthening, education, and health programs on poverty status in Sawahlunto City. The population in this study were the poor in the city of Sawahlunto which were spread over 4 (four) districts, namely 1) Talawi District, 2) Barangin District, 3) Lembah Segar District and 4) Silungkang District totaling 871 families. The number of samples in this study were 96 families. Sampling is done based on Random Sampling with the sampling technique "Cluster Random Sampling" because it has different characteristics. The data analysis used in this research is logistic regression analysis. The results of the study found that the strengthening of capital, education and health both partially and simultaneously had a significant effect on the poverty status of the people in the city of Sawahlunto. Providing business capital, improving education and providing health services that are not burdensome for the poor is one solution to cutting the cycle of poverty. With the availability of business capital, high education and good health, the quality of human resources will be better, so that productivity will increase which will have implications for increasing income and improving the family economy. So that the status of poverty in the city of Sawahlunto can be reduced and the community can get out of the poverty line, it is recommended that the Sawahlunto city government make improvements in providing business capital, improve the quality of human resources by organizing and providing better education and increasing the degree of public health by providing services more equitable health.
\end{abstract}

Keywords: Capital Strengthening, Education, And Health On Poverty Status.

\section{INTRODUCTION}

Poverty is still a serious problem and is closely related to economic growth and income distribution. Various attempts have been made by the government to overcome these poverty problems. Fiscal decentralization policy carried out through fiscal transfers is one of the government policies, which can directly or indirectly have an impact on Indonesian poverty. Poverty is a multidimensional development problem, various perspectives can be used to examine the problem of poverty and formulate steps to solve it. The guideline that is always held in formulating development policies to alleviate poverty is to support and support the development of potentials that exist in society through increasing participation, people's productivity, and efficiency. This means providing ample opportunities for the poor to carry out productive socio-economic activities so as to be able to generate more decent value or income so that they are expected to be more empowered and able to get out of poverty.

Poverty is a phenomenon that is always attempted to be minimized or even eliminated whenever possible. But in reality, poverty is still inherent in every aspect of human life, so that it requires a comprehensive, integral and sustainable poverty reduction effort. Overcoming poverty requires a very long thought and hard work because poverty is so complex that many aspects affect it. In this regard, poverty reduction is a problem that cannot be postponed and must be a top priority in development.

Poverty alleviation programs and the economic, social and institutional characteristics of the poor, need to be reoriented towards approaches in poverty reduction. Considering the following thoughts: (1) Poverty reduction refers to the characteristics and real problems of the poor, (2) Reference to the participatory potential and empowerment and social capital of the poor to get out of poverty, (3) Focus on meeting basic needs, agricultural revitalist, agrarian reform complemented by economic reform, (4) Development of participatory potential, transparency and accountability in the planning, implementation, monitoring and evaluation of programs in poverty by the community.[1]

To fight poverty and improve the quality of people's lives that meet expectations will be the responsibility of 
the Sawahlunto City Government officials together with all levels of society through policies and programs that have been determined. One of the bases for the Regional Government in the context of poverty reduction from the Central Government includes the Minister of Home Affairs Letter Number 412.6 / 2489 / SJ dated 30 October 2002 concerning the Poverty Reduction Committee in the framework of: (1) Compilation of comprehensive and integral short-term and medium-term strategic plans for poverty alleviation, (2) Preparation of Poverty Reduction Strategic Plans adapted to local conditions and culture, (3) Provision of funds through the 2003 Provincial and District / City APBD to support the implementation of poverty reduction in the regions.

Therefore, to reduce the poverty rate, local governments are required to increase innovation and creativity in creating programs to empower the poor in their regions. Sawahlunto City is a small town located in West Sumatra Province, in the past the majority of residents' activities worked as miners, in 1999 after the coal deposit of open-pit mines began to decrease, so that some of the people of Sawahlunto lost their livelihoods where at this time the livelihoods of the Sawahlunto people were mining workers. Civil servants and traders, this causes economic activity in Sawahlunto to decline and the result is an increase in unemployment and an increase in the number of poor people in Sawahlunto City.

Based on data from the Central Statistics Agency (BPS) of Sawahlunto City, the population of Sawahlunto City in 2014 was 56,866 people, with 14,051 households. The number of poor households in Sawahlunto is 1,904 households. Through programs and policies implemented by the City Government of Sawahlunto, which are supported by all levels of society, they have seen positive results with the reduction in the poverty rate in Sawahlunto City. Within a period of 10 (ten) years it has succeeded in reducing the poverty rate by $10.51 \%$, this can be seen in table 1 . below.

Table 1. Percentage of Poor Population by District in Kota Sawahlunto, 2005-2014

\begin{tabular}{|l|c|c|c|c|c|c|c|c|c|c|}
\hline \multirow{2}{*}{\multicolumn{1}{c|}{ District }} & \multicolumn{9}{|c|}{ Percentage of Poor Population } \\
\cline { 2 - 11 } & 2005 & 2006 & 2007 & 2008 & 2009 & 2010 & 2011 & 2012 & 2013 & 2014 \\
\hline Talawi & 2,89 & 1,41 & 1,27 & 1,22 & 1,15 & 0,63 & 0,50 & 0,43 & 0,53 & 0,55 \\
\hline Barangin & 4,24 & 2,06 & 1,87 & 1,79 & 1,70 & 0,93 & 0,73 & 0,63 & 0,79 & 0,81 \\
\hline Lembah Segar & 3,46 & 1,68 & 1,53 & 1,46 & 1,39 & 0,76 & 0,60 & 0,51 & 0,64 & 0,66 \\
\hline Silungkang & 2,89 & 1,41 & 1,27 & 1,22 & 1,15 & 0,63 & 0,50 & 0,43 & 0,53 & 0,55 \\
\hline
\end{tabular}

Source: City Statistics of Sawahlunto (2015)

Based on Table 1.1 above, it can be seen that the reduction in the percentage of poverty in the Distric in Sawahlunto City from 2005-2014. The decrease in the percentage of poverty in Sawahlunto has been carried out by the regional government, including strengthening business capital for small communities (MSMEs), including through the Revolving Fund program and business loans for the poor, policies in education, health and increasing productivity. Of all these are some of the policies taken by the Regional Government of Sawahlunto City in an effort to alleviate poverty, even for 2011 the
Mayor of Sawahlunto has launched an extreme program, namely the program to clean up poverty.

Through the policies that have been implemented on an ongoing basis, it has been able to reduce the poverty rate in Sawahlunto City, and can also increase the overall economic growth in Sawahlunto City. One of the policies of the Sawahlunto Government that has been established and implemented to combat poverty or to build a prosperous society, namely the Allocation of Revolving Funds and Business Loans for the poor can be seen in Table 2.

Table 2. City Human Development Index (HDI) in Sawahlunto, 2005 to 2014

\begin{tabular}{|c|c|c|c|c|}
\hline No & Year & Life expectancy & Literacy Expectation Rate & $\begin{array}{c}\text { Average Length of } \\
\text { Schooling }\end{array}$ \\
\hline 1 & 2005 & 70,01 & 95,4 & 7,5 \\
\hline 2 & 2006 & 70,5 & 97.4 & 7,8 \\
\hline 3 & 2007 & 70,6 & 96,6 & 8,5 \\
\hline 4 & 2008 & 70,6 & 97 & 8,6 \\
\hline 5 & 2009 & 70,80 & 97,87 & 8,6 \\
\hline 6 & 2010 & 70,96 & 97,87 & 8,74 \\
\hline 7 & 2011 & 71,22 & 98,43 & 8,77 \\
\hline 8 & 2012 & 71,44 & 98,5 & 9,13 \\
\hline 9 & 2013 & 71,65 & 98,55 & 9,14 \\
\hline 10 & 2014 & 71,86 & 98,63 & 9,23 \\
\hline & Jumlah & $\mathbf{7 0 9 , 6 4}$ & $\mathbf{9 7 6 , 2 5}$ & $\mathbf{8 6 , 0 1}$ \\
\hline
\end{tabular}

Source: City Statistics of Sawahlunto (2015) 
In table 2. It can be seen that every year there is an increase in the number per year for Life Expectancy, in 2005 there were $70.01 \%$ and in 2014 amounted to $\mathrm{Rp}$ 71.86. The life expectancy rate in Sawahlunto City has increased from year to year, meaning that programs and planning are running in accordance with government systems, regulations and policies in Sawahlunto City, for the 2005 Literacy Expectation Rate of 95.4\%, and in 2014 there were $98.63 \%$, the poor begin to prioritize education, due to changes and improvements from not being able to read or not wanting to attend education, the poor to becoming literate or taking part in education, because the Sawahlunto City Government has lightened the burden and costs on the poor. and the average length of schooling in 2005 was $7.5 \%$ and in 2014 there was an increase of $9.23 \%$. Currently, the poor in Sawahlunto City can continue their highest education.

The autonomy of the poor in the Sawahlunto area has low and limited accessibility to various needs and services compared to those who belong to the middle class and the rich. Access that cannot be obtained by the poor are: (1) Access to adequate food, (2) Access to proper clothing, (3) Access to capital, (4) Access to good and decent health services, (5) Access to educational services, (6) Access to leisure and entertainment, (7) Access to a good quality of life by fulfilling all basic and supporting needs.

The issue of accessibility is important because poverty will become a vicious circle because of it, in which the poor will not be lifted or released from poverty when they cannot increase their intellect and resources. However, due to these accessibility issues, this improvement will be impossible. In the end, as an accumulation of physical and psychological burdens it will cause various negative accesses such as social unrest. Through poverty reduction programs and activities by the City Government of Sawahlunto over the last ten years, it has been able to reduce poverty and also increase the Human Development Index (HDI). However, it is known that the problem of poverty is not only about the number and percentage of poor people, but it must also be able to reduce poverty status (Poverty Status Index).

Based on the foregoing, the researcher is interested in further researching about poverty reduction in the city of Sawahlunto which the author wrote in a thesis research proposal entitled "The Effect of Strengthening Capital, Education and Health on Poverty Status in Sawahlunto City" This study aims to determine and analyze: The effect of capital strengthening programs, education, and health on poverty status in Sawahlunto City.

\section{METHOD}

The research was conducted in the city of Sawahlunto. The scope of the research is a discussion of monitoring of Sawahlunto City government policies, which is approached through several things, namely: (1) Developments in strengthening the revolving fund program business capital and interest-free loans to the poor in Sawahlunto City, (2)
Policies to improve education in the City of Sawahlunto, (3) Policies and improvement of public health in the City of Sawahlunto. In relation to the analytical tool model used to study the influence of Sawahlunto City government policies on the poor, the dependent variable is used, namely Poverty Status (Y). The independent variables are Capital Strengthening (X1), Education (X2), and Health (X3).

Population is the whole symptom / unit to be investigated. [2] The city of Sawahlunto consists of 4 subdistricts, namely 1) Talawi District, 2) Barangin District, 3) Lembah Segar District, 4) Silungkang District, with a total number of poor people, namely 871 households (Sawahlunto City Statistics, 2014). The following table shows the number of poor family heads spread across 4 sub-districts in Sawahlunto City. Suggests that the sample is part of the population which is the actual source of data in a study.[3] The number of population to be taken as a sample in this study because this research is a social research, so it is determined using the Slovin formula.[4]

So the minimum sample size in this study was 90 families divided into 4 villages. Sampling is done based on random sampling with the sampling technique of the population elements in this study using the "Cluster Random Sampling" technique because it has different characteristics. The types and sources of data used in this study are (1) Primary data, namely data obtained at the time of the study which originates from a questionnaire distributed to the poor who are designated as respondents. The answers to the questionnaire were tabulated and analyzed based on research variables, (2) Secondary Data, namely supporting data and information from literature studies and obtained from documents and literature issued by institutions or agencies such as Bappeda, BPS. only taken in Sawahlunto City.

The data collection techniques used in this study are as follows (1) Questionnaire, namely the method of collecting primary data by distributing a list of questions in accordance with the research variables, so that respondents are limited in providing answers to only one alternative to be filled in. The data used in this study are primary data. (2) Documents, namely data collection methods by studying written data sources regarding government policies, organizational structures and other general descriptions to obtain secondary data deemed relevant to this research.

Some of the operational definitions of variables in this study have the following limitations: Poverty status is the percentage of the population that has an average expenditure per capita per month below the poverty line (based on the BPS concept). The poverty line (GK) is the sum of the Food Poverty Line (MKN) and the Non-Food Poverty Line (GKNM) [5]. The measure is the squared poverty gap, which shows the severity or severity of poverty in an area that is given a score of 0 (zero) for poor households and a score of 1 (one) for very poor households. Strengthening business capital is a 
government program provided to poor households in the form of providing business capital with the aim of freeing poor households from poverty. The measurement of the variable of business capital strengthening in this study using a dummy variable, namely a score of 0 for the poor who received additional capital, and a score of 1 for the poor who did not get capital. Education that has been attended by poor household heads. The measure used for the education variable in this study is the dummy variable, namely a score of 0 for the poor who have graduated from junior high school and above, and 1 for the poor who have not graduated from junior high school. The physical condition of the head of a poor household as indicated by the number of sick days in one (1) year. The measurement used is the Dummy variable, namely 0 for the head of the household who has never experienced illness for 14 days in the last 1 (one) year and 1 for the head of the household who has been sick for 14 or more working days in the last one year.

The analysis technique is used to describe each research variable in the formulation of the variable model of poverty, capital strengthening, education, and health. The data used to describe the poor is first analyzed descriptively which is used to see the relationship between poverty status and the socio-economic community which is presented in the form of distribution tables so that it will reflect the symptoms that answer the problems in the study, descriptive analysis can also describe the using the method of score and level of achievement. The mean is the average score of the total number of respondents' answers which is the limit to determine the level of the category of results achieved for 1 question or indicator (where to find the standard results from the specified medium standard). To obtain an average score, the mean formula is used, as follows: [3]. To see the functional relationship between poverty status with the variables of strengthening capital, education level and health. The results of this final analysis can see the implications of the research results on the strategies and policies that will be taken for poverty alleviation / solutions. Quantitative analysis can use Multiple Logistic Regression Model [6]. Analysis to show the probability of a household being in poverty based on assumptions about the random variable being studied and can also determine the degree of difference in the subfactor or component of the object under study statistically with the equation. The model above will be estimated using the Maximum Likelihood approach using the SPSS program to determine the effect of independent variables on the dependent variable. Chi Square Test (X2): the indicator that shows whether this connection exists or not is (Chi Square Test). The value of X2 can be obtained by two calculation methods and by using the table $\mathrm{H}$ list. The two X2 values above will then be compared. If the X2 result of the calculation is greater than the value of $\mathrm{X} 2$ using the $\mathrm{H}$ list, then the hypothesis used is accepted or there is a relationship between the two factors analyzed. If the value of $\mathrm{X} 2$ is less than the value of $\mathrm{X} 2$ in the list $\mathrm{H}$, then the hypothesis is rejected or there is no relationship between the two factors analyzed. Odd Ratio Test To determine whether a household is poor or not [6]. To test the effect of individual independent variables on the dependent variable, a Wald Test was performed [7]. (1) If $\mathrm{t}$ count $>\mathrm{t}$ table, then Ho is rejected, meaning that the independent variable $\mathrm{Xi}$ has a significant effect on the dependent variable. (2) If $t$ count $<t$ table, then Ho is accepted, it means that the independent variable $\mathrm{Xi}$ has no effect on the dependent variable.

\section{RESULTS AND DISCUSSION}

\subsection{Descriptive Analysis}

This research variable description aims to see the characteristics of the variables that determine poverty status in Sawahlunto City in order to reduce the poverty status that occurs in West Sumatra, especially in Sawahlunto City. To describe these variables, they can be categorized into the dominant factors that determine the poverty status of the people in Sawahlunto City. In this study, there are 3 research variables that affect poverty status in Sawahlunto City which can be seen in each of the descriptions of the following research variables:

Strengthening capital for businesses of small and medium-sized communities and poor families with the aim of fostering community business development, so that they are empowered and produce value so that they are able to compete among the general public and be able to get out of what is called poverty. The description of the strengthening of business capital from the research results is described as consisting of 2 indicators, namely the poor who have received business capital and the poor who have not received business capital. Table 3.The following shows an overall picture of the variables of strengthening business capital:

Table 3. Frequency distribution of business capital strengthening on the poverty status of the people of Sawahlunto city

\begin{tabular}{|l|c|c|}
\hline \multirow{2}{*}{ Indicator } & \multicolumn{2}{c|}{ Value } \\
\cline { 2 - 3 } & Frequency & Percentage \\
\hline Obtaining business capital & 55 & 61.11 \\
\hline Did not get business capital & 35 & 38.89 \\
\hline Total & $\mathbf{9 0}$ & $\mathbf{1 0 0 . 0 0}$ \\
\hline
\end{tabular}

Primary data sources were processed in 2015 
Based on Table 3. the variable of business capital strengthening from 90 research respondents, as many as 55 families $(61.11 \%)$ had received business capital from the city government of Sawahlunto, while 35 families (38.89\%) never received business capital assistance. This shows that the strengthening of business capital provided by the city government of Sawahlunto to the community obtained an achievement level of $61.11 \%$. The achievement level classification between $55 \%-64 \%$ is in the unsatisfactory classification. This means that the business capital assistance provided by the Sawahlunto city government to the poor is still not evenly distributed, because there are still poor people who have not received business capital assistance. [3]
Education is one indicator in determining the quality of human resources as a workforce. Education is also a reflection of the progress of a citizen, because those with a higher education will create and innovate a lot. The education level of respondents is measured based on the years of formal education they have attended, from the lowest level of education to the highest.

The description of the educational level of the research results is described as consisting of 2 indicators, namely the poor who have graduated from junior high school and above and those who have not graduated from junior high school. Table 4.The following shows an overall picture of the education level variables of the poor in the city of Sawahlunto:

Table 4. Frequency distribution of education level on poverty status of the people of Sawahlunto city Value Indicator

\begin{tabular}{|l|c|c|}
\hline \multirow{2}{*}{ Indicator } & \multicolumn{2}{c|}{ Value } \\
\cline { 2 - 3 } & Frequency & Percentage \\
\hline Completed junior high school and above & 58 & 64.44 \\
\hline Did not complete junior high school & 32 & 35.56 \\
\hline Total & $\mathbf{9 0}$ & $\mathbf{1 0 0 . 0 0}$ \\
\hline
\end{tabular}

Primary data sources were processed in 2015

Based on Table 4, the educational level variables of the 90 research respondents, as many as $58(64.44 \%)$ had a junior high school level and above, while 32 (35.56\%) had a junior high school education level. This shows that the level of education of the poor in Sawahlunto is an achievement level of $64.44 \%$. The achievement level classification between $55 \%-64 \%$ is in the unsatisfactory classification. This means that the level of education owned by the people of Sawahlunto is still not satisfactory, so it is natural that the poverty rate in the city of Sawahlunto is very high [3].

Health is a maximum condition, both physically, mentally and socially, so that with the health that is owned the community can carry out an activity, can work optimally which results in better income / income. The description of the health of the poor in the city of Sawahlunto, the results of the study, consists of 2 indicators, namely people who have never experienced illness for 14 days in the last 1 (one) year and people who have been sick for 14 or more working days in the last one year. Table 5.The following shows an overall picture of the health variables for the poor in the city of Sawahlunto:

Table 5. Health frequency distribution to the poverty status of the people of Sawahlunto city

\begin{tabular}{|l|c|c|}
\hline \multicolumn{1}{|c|}{ Indicator } & \multicolumn{2}{|c|}{ Value } \\
\cline { 2 - 3 } & Frequency & Percentage \\
\hline $\begin{array}{l}\text { Have been sick for 14 or more working days } \\
\text { in the past year }\end{array}$ & 37 & 41.11 \\
\hline $\begin{array}{l}\text { Never experienced illness for 14 days in the } \\
\text { last 1 (one) year }\end{array}$ & 53 & 58.89 \\
\hline Total & $\mathbf{9 0}$ & $\mathbf{1 0 0 . 0 0}$ \\
\hline
\end{tabular}

Primary data sources were processed in 2015

Based on Table 5, the health variables of the 90 study respondents were $37(41.11 \%)$ Have been sick for 14 or more working days in the past year, while $53(58.89 \%)$ have never experienced illness for 14 days in 1 (one) last year. This shows that the level of health of the poor in Sawahlunto is an achievement level of $58.89 \%$. The achievement level classification between $55 \%-64 \%$ is in the unsatisfactory classification. This means that the health status of the poor in Sawahlunto is still unsatisfactory. As we know, nowadays medical costs are very expensive, almost every medical clinic, let alone the hospital, applies a tariff or medical fee that is soaring, so that the cost is not affordable for the poor [3].

Poverty has multiple forms including low income and productive resources ensuring a sustainable life, hunger and malnutrition, low levels of health, limited and lack of access and other basic services. Poverty is also a major 
problem currently being faced by the people of Sawahlunto. Poverty is characterized by high levels of unemployment and low levels of education. The poor are generally weak in fulfilling their daily needs, weak in the ability to open business fields and have limited access to economic activities.
The description of the poverty status of the people in the city of Sawahlunto, the results of the study, consists of 2 indicators, namely the poor and the very poor. The following Table 6 shows an overview of the poverty status of the people in the city of Sawahlunto:

Table 6. Frequency Distribution Table of Poverty Status (Y)

\begin{tabular}{|l|l|c|c|}
\hline \multirow{2}{*}{ No. } & \multirow{2}{*}{ Indicator } & \multicolumn{2}{|c|}{ Value } \\
\cline { 3 - 4 } & & Frequency & Percentage (\%) \\
\hline 1. & Poor & 56 & 62.22 \\
\hline 2. & Very Poor & 34 & 37.78 \\
\hline Jumlah & $\mathbf{9 0}$ & $\mathbf{1 0 0 . 0 0}$ \\
\hline
\end{tabular}

Source: Primary data (processed in 2015)

Based on Table 6, it can be seen that the poverty status of the people of Sawahlunto city of 90 respondents, 51 $(56.67 \%)$ of respondents belong to the poor category, while $39(43.33 \%)$ respondents are in the very poor category. This means that $56.67 \%$ of the poor in Sawahlunto are not far below the poverty line. By providing business capital on a regular basis, increasing the level of education, knowledge and skills and improving the health status, groups of people who are not far below the poverty line can be excluded from the poverty circle, while $43.33 \%$ of respondents are far below the poverty line. Poverty has multiple forms including low income and productive resources ensuring a sustainable life, hunger and malnutrition, low levels of health, limited and lack of access and other basic services.

\subsection{Logistic Regression Analysis}

\subsubsection{Wald Test}

The Wald Test is conducted to test the effect of the independent variables individually on the dependent variable. (a) Strengthening Business Capital has a significant effect on the level of poverty status of the people of Sawahlunto. In the hypothesis test, it was found that thit $=6.153$ lies in Sig. $0.013<0.05$ then H0 is rejected, Ha is accepted. This means that there is a significant influence between the variables of strengthening business capital on the poverty status of the people of Sawahlunto. In the Wald test hypothesis, it can be seen from the degrees of freedom (df) $=\mathrm{n}-\mathrm{k}-1=100-2-1=97$ and $\alpha=0.05$, it is obtained $\mathrm{t}$ hit $=6.153$ and the value of $\mathrm{t} t \mathrm{ta}=1.98472$. Thus $\mathrm{t}$ hit $>\mathrm{t}$ tab, then the hypothesis is accepted. (b) Education has a significant influence on the poverty level status of the people of Sawahlunto. In the hypothesis test, it was found that thit $=4,215$ lies in Sig. $0.040<0.05$ then H0 is rejected, $\mathrm{Ha}$ is accepted. This means that there is a significant influence between the education variables on the poverty status of the people of Sawahlunto. In the Wald test hypothesis test, it is seen from the degrees of freedom (df) $=\mathrm{n}-\mathrm{k}-1=100-2-1=97$ and $\alpha=0.05$, it is obtained $\mathrm{t}$ hit $=4.215$ and the value of $t \mathrm{tab}=1.98472$. Thus $\mathrm{t}$ hit $>\mathrm{t} t \mathrm{tab}$, then the hypothesis is accepted. (c) Health has a significant influence on the poverty level status of the people of
Sawahlunto. In the hypothesis test, it was found that thit = 9,682 was located in Sig. $0.002<0.05$ then H0 is rejected, $\mathrm{Ha}$ is accepted. This means that there is a significant influence between the health variables on the poverty status of the people of Sawahlunto. In the Wald test hypothesis test, it is seen from the degrees of freedom (df) $=\mathrm{n}-\mathrm{k}-1=100-2-1=97$ and $\alpha=0.05$ obtained $\mathrm{t}$ hit $=$ 9.682 and the value of $t \mathrm{tab}=1.98472$, thus $\mathrm{t}$ hit $>\mathrm{t} t \mathrm{tab}$, then the hypothesis is accepted.

\subsection{Chi Square Test $\left(X^{2}\right)$}

Based on the formulation of the research problem, namely to determine the influence of the variables of strengthening business capital, education, and health on the poverty status of the people of Sawahlunto city. By using Logistic Regression. Chi Square aims to determine the effect simultaneously (simultaneously) on the variables of strengthening business capital, education and health on poverty status. From the test results of logistic regression analysis, the Chi Square value was 1.552 with a Sig value of 0.992 . From these results, it can be seen that the Sig value is greater than alpha $(0.05)$, which means that the decision taken is to accept $\mathrm{H}_{0}$, meaning that there is no difference between the predicted classification and the observed classification. This means that together all (simultaneously) variables of strengthening business capital, education and health on poverty status.

\subsection{Odd Ratio Test}

Based on the results of the model significance test, it can be seen that the $\mathrm{X} 1$ variable (capital strengthening) is significant at 0.013 , the $\mathrm{X} 2$ variable (education) is significant at 0.040 , and the $\mathrm{X} 3$ variable (health) is significant at 0.002 . From the above equation, it can be interpreted that a constant value of 39.123 shows that there is no influence from the independent variables, namely strengthening of capital, education and health, so the poverty status of the people of Sawahlunto city is reduced by 39.123 units. 
Table 7. Logistic Regression Coefficient Value

\begin{tabular}{|l|c|c|c|c|c|c|c|}
\hline \multicolumn{2}{|c|}{} & B & S.E. & Wald & Df & Sig. & $\operatorname{Exp(B)}$ \\
\hline $\begin{array}{l}\text { Step } \\
1(\mathrm{a})\end{array}$ & $\mathrm{X} 1$ & .334 & .135 & 6.153 & 1 & .013 & 1.397 \\
\hline & $\mathrm{X} 2$ & .766 & .373 & 4.215 & 1 & .040 & .465 \\
\cline { 2 - 8 } & $\mathrm{X} 3$ & 1.079 & .347 & 9.682 & 1 & .002 & 2.941 \\
\hline & Constant & 39.123 & 13.167 & 8.828 & 1 & .003 & .000 \\
\hline
\end{tabular}

Source: Primary data processed in 2015

From Table 8 above, the logistic regression equation is obtained as follows:

$$
\mathrm{Y}=39,123+0,334 \mathrm{X} 1+0,766 \mathrm{X} 2+1,079 \mathrm{X} 3+\mathrm{e}
$$

The variable of business capital strengthening (X1) has a positive regression coefficient of 0.334 , which states that the better the strengthening of business capital is given to the community, the community's economy will increase and the poverty status that occurs in the people of Sawahlunto city will decrease. If the variable of business capital strengthening increases by one unit, then the poverty status of the city of Sawahlunto (Y) will increase by 0.334 assuming the other independent variables are constant. Then, seen from the results of the odd ratio analysis, the business capital strengthening variable (X1) has a value of 1.397. This means that the tendency for the level of poverty in the community who get business capital strengthening in the city of Sawahlunto is 1,397 times smaller than that of people who do not get business capital loans. This means that the strengthening of business capital provided by the city government of Sawahlunto is proven to reduce the poverty status that occurs in the people of Sawahlunto city. By strengthening business capital, it will make the people's economy better.

The education variable (X2) has a positive regression coefficient of 0.766 , which states that the higher the level of education of the community, the lower the poverty status that occurs in the people of Sawahlunto. If the education variable increases by one unit, the poverty status of the city of Sawahlunto (Y) will decrease by 0.766 , assuming the other independent variables are constant. Then, seen from the results of the odd ratio analysis, the education variable (X2) has a value of 0.465 . This means that the tendency for the level of poverty status in people who have higher education or have graduated from junior high school and above is 0.465 times smaller than in people whose education has not graduated from junior high school. This means that the education that the people of Sawahlunto have is proven to reduce poverty status. The higher the education that is owned by the community, the better the job will be obtained, the better the work that is engaged, the higher the income / income, so that the family economy will be better, so that the community can move out of the poverty line.

The health variable (X3) has a positive regression coefficient of 1.079 which states that the better the health level of the community, the higher the desire of the community to try to change its economic condition. If the health variable increases by one unit, the poverty status of the people of the city of Sawahlunto (Y) will decrease by 1.079 on the assumption that the other independent variables are constant. Then, seen from the results of the odd ratio analysis, the health variable (X3) has a value of 2.941. This means that the tendency for the level of poverty status in people with a higher degree of health and education is 2.941 times smaller than that in people with a low level of health. This means that the health of the people of the city of Sawahlunto is proven to reduce poverty status. The higher the level of health the community has, the better the job will be, the better the job, the higher the income / income, so that the family economy will be better, so that people can get out of the poverty line.

\subsection{Discussion}

The discussion in this study aims to explain and interpret the results of research with research objectives. Based on the results of the analysis that has been carried out, there is an influence between the independent variables and the dependent variable, namely:

The results of the research analysis conducted show that strengthening business capital has a significant effect on the poverty status of households in the city of Sawahlunto, where strengthening business capital has a positive effect on the poverty status of the people of Sawahlunto city. Thus the influence of the variable of strengthening business capital for the people of Sawahlunto city indicates that to be able to open a business to increase better income requires sufficient business capital. Strengthening business capital for small and medium-sized communities and poor families with the aim of fostering community business development, so that they are empowered and generate value so that they are able to compete among the general public and be able to get out of what is called poverty Strengthening business capital is a stimulation of funds for people who experience limited capital. Facilitating the strengthening of business capital is part of the community empowerment effort, which is escorted by related activities, namely strengthening community institutions and improving community human resources through coaching, counseling, training, monitoring, evaluation, and others. The objectives of community empowerment through strengthening business capital are as follows: (a) Strengthening the capital of business actors in developing business and food security. (b) Increase production, productivity and income of business actors. (c) Developing businesses in the development area. (d) 
Increase independence and cooperation. (d) Encouraging the development of microfinance institutions and other economic institutions. The success (outcome) of community empowerment activities through strengthening group business capital includes: (a) The growth of group businesses capable of managing capital according to business principles through the use of business capital funds according to targets. (b) An increase in the productivity of business capital fund recipients. (c) The occurrence of capital accumulation and returns / revolutions of the components that must be rolled out so that they can reach a wider target group. Meanwhile, the success (impact and benefit) of community empowerment through strengthening group business capital, among others, reduces the poverty rate gap that occurs. Theoretically the results of this study are in line with the theory presented which states that poverty, poverty arises because of differences in access to and ownership of capital due to limitations and orderly access and human business capital has limitations, even there is no choice to develop their life, except doing what is forced now that can be done, not what should be done. Thus humans have limitations in making choices, as a result, human potential to develop their lives is hampered [8].

The results of the research analysis conducted show that education has a significant effect on the poverty status of households in the city of Sawahlunto, where the level of education has a positive influence on the poverty status of the people of Sawahlunto. Thus the influence of the variable level of education in the city of Sawahlunto indicates that to get a better job requires a better level of education. This is due to the increasingly complex knowledge that the people of Sawahlunto must have in an effort to exploit existing natural resources, as a source of livelihood for the people of Sawahlunto. Low levels of education will result in low knowledge and skills of the people of Sawahlunto who are members of the workforce. This means that one of the social forces to improve the long-term economy of the people of Sawahlunto is very low. The low level of education of the people of Sawahlunto has made them less able to access various changes and information. With this inability, there are many possibilities that can happen. Some of them are the low probability of being accepted into a better job market. In addition, it also causes them to be slow to accept or adopt an innovation, both in the form of ideas and in material form. However, the level of education will affect the quality of human resources, thus it is concluded that, the people of Sawahlunto city who have a higher level of education will have high productivity, because higher education will be balanced with the mastery of increasingly diverse and quality factors, and will eventually bring them out of poverty. Theoretically, the results of this study are in line with the theory presented which states that the internal factor that causes poverty in the people of Sawahlunto is the limited quality of human resources.[9] Furthermore, the results of this study are also in accordance with Kartasasmita's which states that poverty conditions can be caused by low levels of education [10]. The low level of education results in limited self-development capacity and results in narrow jobs that can be entered. Low levels of education also limit a person's ability to seek out and take advantage of opportunities. Furthermore, the results of this study are also consistent with the study of Masyhuri which states that people who have low education are often seen as synonymous with poverty. It is further said that apart from being poor, they are considered weak, stupid, inefficient and unable to determine their own destiny and needs.[11]. Therefore, the role of education for the community is very important to be able to empower family communities from poverty problems. Based on the research results, it can be concluded that education has many functions, especially in development, this can be seen from the function of education to develop skills and other abilities needed to enter the world of work or become a productive society. Education is also seen as a social enterprise. Education is given to those who need to improve their abilities. The implementation of education is aimed at the occurrence of changes in people's lives for the better. Thus it is very clear that the influence of education is very large on changes in society, in increasing the welfare of society, especially in the economy.

The results of the analysis of the research conducted show that health has a significant effect on the poverty status of the people in the city of Sawahlunto, where health has a positive influence on the poverty status of the people of Sawahlunto. Thus the influence of the public health variable in the city of Sawahlunto indicates that to be able to work and earn a better income requires a better health degree. This means that health is a very important investment to support economic development and has an important role in poverty reduction efforts. As we know, now medical costs are very expensive, almost every medical clinic, let alone a large private hospital, applies a tariff or medical fee which is soaring, so that the cost is not affordable for the poor. For this reason, health development must be seen as an investment to improve the quality of human resources. In measuring the Human Development Index (HDI), health is one of the main components besides education and income. In Law Number 23 of 1992 concerning Health, it is stipulated that health is a state of well-being of body, soul and society which enables everyone to live productively socially and the economy. Theoretically, the results of this study are in line with the theory presented by Kartasasmita which states that poverty conditions can be caused by low levels of health. Low levels of health and nutrition lead to low physical endurance, power of thought and initiative, which in turn will have implications for the low quality of human resources, so that productivity levels will also be low. [10] The results of this study are also in accordance with the vicious circle of poverty theory, which states that the poor have low incomes, so they do not have the ability to invest in education, including investing in health. The inability to invest in health will have implications for the low quality of human resources, resulting in low productivity levels. Low productivity levels will lead to low income. To be able to increase productivity, it requires strengthening business capital in order to open a 
business in order to increase better income. Providing business capital, education and health services that is not burdensome for the poor is one solution that can be chosen to cut the vicious cycle of poverty. With the availability of free business capital, education and health for the poor, the quality of human resources will be better, so that productivity will increase which will have implications for increased income, so that this increase in income will increase purchasing power and investment, reflecting the welfare of the community. high.

\section{CONCLUSIONS}

Based on the results of research that has been conducted on the effect of strengthening business capital, education and health on the poverty status of the people of Sawahlunto, the following conclusions can be drawn: (a) Strengthening business capital has a significant effect on the poverty status of the community in the city of Sawahlunto with an effect value of 0.334 (Sig $=0.013)$. (b) Education has a significant effect on the poverty status of the people of Sawahlunto. People who have a high level of education will automatically try to find a better job so that the economic conditions of the family improve, which in turn can get out of the cycle of poverty. (c) Health has a significant effect on the poverty status of the people of Sawahlunto. Health is an investment to support economic development and has an important role in poverty reduction efforts

From the results of the above research, several suggestions can be put forward as follows: (a) There is a need for improvements in providing business capital to the community in a rotating, sustainable and equitable manner with stimulation of funds for people who experience limited business capital. Facilitating the strengthening of business capital is part of efforts to empower the community and increase community human resources through coaching, counseling, training, monitoring, evaluation, and others. (b) In order to improve the quality of human resources, it is recommended that the city government of Sawahlunto be able to organize and provide education and training to the community, with the education and training provided it is hoped that it will make it easier for the community to access, receive and study any existing information, so that changes in life occur. society towards a better direction and provide a positive impact on the pattern of life and increase community economic activities. (b) It is necessary to improve the degree of public health by providing quality health workers and their distribution is evenly distributed, so that health services provided are more equitable and affordable for the poor. In addition, it is suggested to the public to support the health program activities carried out by the government by implementing a clean and healthy lifestyle.

\section{REFERENCES}

[1] A, IDBM, and E. Hermiati. 2003. Local Livelihood Patterns: A Reference for Assessing Poverty in the Era of Regional Autonomy (Case of East Nusa Tenggara Province). Journal of People's Economics. Year I Article No. February 12, 2003.

[2] P, Bambang and Lina Miftahul Jannah, 20005, Quantitative Research Methods: Theory and Application, Jakarta: PT Raja Grafindo Persada.

[3] S,yono, 2009. Statistics for research, Alfabeta Publisher. Bandung

[4] G, Imam. 2005. Application of Multivariate Analysis with SPSS Program. Semarang: Diponegoro University Publishing Agency.

[5] Central Bureau of Statistics (2008), West Sumatra Economic Report (Population, Workforce, Consumption Patterns, and Population Poverty). Padang

[6] A, gung, (1996), Statistics Analysis of Causal Relationships Based on Categorical Data. Jakarta: Rajawali Press.

[7] N, Djalal, (2002), Penggunaan Teknik Ekonometrik, Jakarta: PT Raja Grafindo Persada.

[8] K, Mudrajat. 2000. Development Economics, Theory, Problems and Policy. Yogyakarta: UPP AMP UPKN.

[9] K, usnadi, (2004). Fishermen Poverty Polemic. Pustaka Jogja Mandiri.

[10] M, asyhuri (1999), Empowerment of Underdeveloped Fishermen in Overcoming the Economic Crisis, An Analysis of an Approach, Jakarta: Center for Economic Research and Development of LIPI.

[11] R, Faturrohmin. (2006). The Effect of PDRB, Life Expectancy, and Literacy on Poverty Levels in 35 Districts / Cities in Central Java. Jakarta: UIN Syarif Hidayatullah. 